\title{
Tribunal do Júri: uma análise histórica e principiológica às suas decisões sobre o prisma da segurança jurídica
}

\author{
Jury Trial: a historical analysis and set of principles for their decisions regarding the aspect of \\ legal security.
}

\author{
Camila Martins Tonello ${ }^{1}$ \\ Danilo Rodrigues ${ }^{2}$
}

\section{Resumo}

O estudo repousa na pesquisa do histórico e da evolução do Tribunal do Júri. Por conseguinte, expõe a ausência de motivação da sentença do Tribunal do Júri como conseqüência da incomunicabilidade entre os jurados. Relata a necessidade de se discutir mudanças no procedimento de modo a garantir maior segurança jurídica aos acusados, a fim de preservar a concepção grega do instituto. Não se podem privar os jurados de discutirem e analisarem entre si o crime que estão julgando, trata-se de uma das principais ferramentas da democracia: a dialética. Fruto de longos debates em comissões, os doutrinadores vieram por sugerir ao legislador um novo texto para o procedimento no Tribunal do Júri, o qual passará a constar do Novo Código de Processo Penal, em discussão atualmente na Câmara dos Deputados. O novo artigo permitirá aos jurados o debate entre si por uma hora inteira antes de proferirem o veredito, significando a retomada de um direito fundamental ofuscado com as sombras da ditadura.

Palavras chave: Tribunal do Júri; Incomunicabilidade; Segurança Jurídica.

\begin{abstract}
The study is based on research into the history and evolution of the jury. Therefore, exposes the lack of motivation of the verdict of the Jury as a consequence of the inability of the jury. Reports the need to discuss changes in procedures to ensure greater legal certainty to the accused in order to preserve the Greek conception of the institute. We can not deprive the jury to discuss and analyze each other crime they are judging, it is one of the main tools of democracy: the dialectic. The result of long debates in commissions, scholars came to the legislature by suggesting a new text for the procedure in the grand jury, which will appear in the New Code of Criminal Procedure, currently under debate in the House of Representatives. The new rule will allow jurors to debate among themselves for a full hour prior to issuing the verdict, meaning the return of a fundamental right obscured in the shadows of dictatorship.
\end{abstract}

Keywords: Jury Trial; Incommunicado; Legal Security.

1 Graduada em Direito pela Universidade Estadual de Londrina e pós-graduanda em Direito Constitucional pelo Instituto de Direito Constitucional e Cidadania.

2 Graduado em Direito pela Universidade Estadual de Londrina. 


\section{Introdução}

A criação do Tribunal do Júri, um dos mais antigos órgãos de julgamento existente no mundo, antecede até mesmo os limites do Estado organizado. Desde sua concepção, o instituto em comento sofreu inúmeras transformações em todos os países que o copilavam, em virtude dos diversos modos com que os Estados resolveram tratar das questões de sua competência e do seu peculiar procedimento.

No Brasil, o Tribunal Popular foi instituído em 1822, antes mesmo do advento da primeira Constituição Nacional. Sob a égide da Carta Cidadã de 1988, verifica-se que a maior contenda enfrentada pelo Poder Judiciário é a de submeter-se aos ditames do Estado Democrático de Direito, fazendo com que o Tribunal do Júri seja ainda uma ferramenta para que isso se perfaça.

Ocorre, no entanto, que as normas constitucionais que estruturam sobredito instituto são, em algumas vezes, aparentemente conflitantes entre si, exigindo uma exegese especial para que se extraia a verdadeira norma a ser cumprida.

Como se pode verificar, peculiar aspecto referente ao veredito proferido pelos jurados corresponde ao fato de que o magistrado ao prolatar a sentença, seja ela condenatória ou não, prescinde de fundamentar sua decisão, uma vez que esta advém da livre manifestação dos jurados, que de igual modo estão também dispensados de fundamentar sua decisão.

Como se pretende demonstrar, dita situação se revela encampada nos princípios próprios informadores do Tribunal do Júri, exarados no texto da Lei Maior.

Face a essa exposição, o presente trabalho tem por fito analisar a segurança jurídica a qual se submeterá o acusado a ser julgado pelo Tribunal Popular, a partir do surgimento do instituto, de seu desenvolvimento no Brasil, ao longo da história constitucional, e por fim, da forma com que se chega ao veredito final.

Almeja, sem a pretensão de esgotar a reflexão acerca da proposição apresentada, discutir à luz da Carta Política de 1988, a necessidade ou não de fundamentação da sentença do Tribunal do Júri. 
Tribunal do Júri: uma análise histórica e principiológica às suas decisões sobre o prisma da segurança jurídica

\section{Breve contextualização histórica}

A origem do instituto do Tribunal do Júri é imprecisa e muito discutida, dado que se remete às civilizações antigas e de modo diferente que a concebemos atualmente. (RANGEL, 2009, p. 539). Relatos mais antigos sobre a existência do Tribunal do Júri podem ser encontrados no supra livro Pentateucho, o qual descreve a história da civilização antiga do Egito escrita pelos judeus sob o comando de Moisés. (ROCHA, 1919 apud BORBA, 2002).

Segundo as leis mosaicas, a origem do instituto está vinculada à idéia máxima do julgamento pelos pares. Isto é, o julgamento do cidadão comum deveria ser realizado senão por outros cidadãos comuns. Nelas estão previstas ainda os princípios fundamentais dessa instituição, bem como todo o seu peculiar rito processual.

Entretanto, a origem grega é doutrinariamente a mais aceita do Tribunal do Júri, pois foi por volta do século $V$ a.C. que se consolidaram na Grécia as participações populares nas questões relativas ao governo. Dessa forma, a idéia de participação democrática, em sua essência, nos assuntos de ordem pública, justificadamente caracteriza a base dessa instituição (MAMELUQUE, 2008, p. 33).

O fato de o júri ter sobrevivido a centenas de anos e se propagado a tantos outros países e ordenamentos jurídicos diferentes é, nas palavras de Emerico Amari (1860 apud NUCCI, 2008, p. 731), advindo da "própria e inata contagiosidade do direito" capaz de levar a outros povos o que uma nação tem de mais moderno e proveitoso.

Com absoluta propriedade sobre o tema, nos ensina o doutrinador argentino Alberto Binder que a necessidade de se garantir a existência do Tribunal Popular se faz, ausente a impessoalidade do magistrado, ao julgar crimes que o provoque intervenção de sentimentos pessoais, uma vez que sua decisão não se trata de mera operação lógica (BINDER, 1999, p. 84).

\section{Do desenvolvimento do instituto no Brasil}

A institucionalização do Tribunal do Júri no Brasil se deu com o advento da Lei de 18 de julho de 1822, tempos antes da independência e da primeira Constituição brasileira, de 1824, promulgada sob o regime monarquista recém existente no Brasil (RANGEL, 2009, p. 
544). Nesse primeiro momento, o Tribunal do Júri tinha competência para julgar os crimes de imprensa, e era formado por:

[...] juízes de Fato, num total de vinte e quatro cidadãos bons, honrados, patriotas e inteligentes, os quais deveriam ser nomeados pelo Corregedor e Ouvidores do crime, e a requerimento do Procurador da Coroa e Fazenda, que atuava como o Promotor e o Fiscal dos delitos. Os réus podiam recusar dezesseis dos vinte e quatro nomeados, e só podiam apelar para a clemência real, pois só ao Príncipe cabia a alteração da sentença proferida pelo Júri (BORBA, 2002).

Na Constituição Imperial de 1824, o Tribunal Popular foi tratado no capítulo que dispunha sobre o Poder Judiciário. Porém, a legislação foi alterada várias vezes, modificando consequentemente a competência do Júri (NUCCl, 2008, p. 732).

Na sua primeira década de existência no Brasil, o instituto do Júri, bem como todo o órgão judicial, ainda estava vinculado aos poderes monarquistas e aos interesses dos traficantes de escravos, aliados aos anseios latifundiários e comerciais da jovem política externa existente. Esse fato fez com que as suas decisões fossem controladas, "pelos grandes proprietários, que absolviam os poucos acusados que iam a julgamento" (RANGEL, 2008, p. 545).

As reformas processualistas ocorridas historicamente nessa época, mais precisamente em 1832, com o advento do Código de Processo Criminal do Império, criaram o Grande Júri, responsável por decidir se procedia ou não a acusação contra o acusado, e o Pequeno Júri que efetivamente proferia o julgamento em plenário (RANGEL, 2008, p. 545546).

Posteriormente, a Lei Imperial número 261, de 31 de Janeiro de 1842, revogou a existência do Grande Júri, passando às autoridades policiais e aos juízes municipais a sua competência. Esses integrantes eram nomeados pelo Imperador, e a escolha dos jurados consistia em incumbência dos delegados de polícia, culminando na conformidade das decisões do Tribunal do Júri aos interesses da Corte.

Porém, como o cenário político fora bastante conturbado durante o período do Império, este agia exclusivamente conforme os seus interesses. E foi nesse aspecto que, após vencer a Guerra do Paraguai, e pressionado pelas idéias reformistas da sociedade latifundiária, Dom Pedro II editou, no de 1871, a Lei número 2.033, que atribuía agora a fase de formação de culpa e pronúncia do acusado a juízes de direito (RANGEL, 2009, p. 550). 
Tribunal do Júri: uma análise histórica e principiológica às suas decisões sobre o prisma da segurança jurídica

A primeira Constituição da República do Brasil, e segunda constituição nacional, promulgada com influência dos ideais políticos, econômicos e sociais dos Estados Unidos, instituiu, em 24 de fevereiro de 1981, o Tribunal do Júri. Este instituto fora disciplinado no capítulo referente aos direitos dos cidadãos brasileiros, impedindo, destarte, que nenhuma lei infraconstitucional posterior pudesse alterar a sua essência (RANGEL, 2009, p. 551).

Com a crescente crise econômica alavancada pela queda da bolsa de Nova lorque, o setor cafeeiro no Brasil reage e os jovens militares iniciam uma Revolução que marcaria para sempre a história de nosso país: a Revolução de 1930, de Getúlio Vargas. Nesse cenário surge a Carta de 1934, a qual, apesar de disciplinar o Tribunal do Júri, no capítulo referente ao Poder Judiciário, não mais o tratava como um direito do cidadão. Era o começo de uma série de mudanças que estava por acontecer.

Com o golpe de Estado e o início do regime ditatorial estabelecido pelo Estado Novo, em 10 de novembro de 1937, o Tribunal Popular sequer foi citado no texto magno, uma vez que, "na medida em que o regime é endurecido, o governo precisa intervir no Judiciário e dificultar a liberdade e facilitar a repressão com a seqüente condenação" (RANGEL, 2009, p. 551). Assim, devido a omissão do texto constitucional, várias foram as discussões sobre a manutenção ou não dessa instituição no ordenamento jurídico brasileiro.

Foi então que em 1938, o Decreto número 167, de 5 de janeiro, confirmou a sua existência, não lhe atribuindo, porém, soberania. (NUCCl, 2008, p. 731), o que culminou na possibilidade de revisão e alteração de todas as suas decisões pelo Tribunal de Apelação (RANGEL, 2009, p. 558). É a primeira vez que os jurados são impedidos de comunicarem entre si durante toda a sessão de julgamento.

Com o debacle do regime ditatorial e fascista no continente europeu, Getúlio Vargas foi rapidamente deposto por forças revolucionárias brasileiras que, em 29 de outubro de 1945, assumiram o poder e prometeram uma nova fase na política nacional. A democracia seria restaurada.

Foi então que, em 18 de setembro de 1946, é promulgada no Brasil a nova Constituição da República, a qual tratou de colocar o Tribunal do Júri novamente no capítulo referente aos direitos e garantias individuais. Não obstante, os ideais de democracia e liberdade encontravam-se dessa vez deturpados pelo poder coronelista, preocupado em 
garantir sua existência, o que culminou, consequentemente, na necessidade de um Poder Judiciário vinculado aos seus domínios (NUCCl, 2008, p. 43-44).

A decisão do Júri passa a ser tratada como soberana não sendo possível a sua revisão pelo Tribunal de Apelação, revelando a nova ordem democrática e constitucional que o país vivenciaria nos próximos anos, embora sobre forte influência dos interesses coronelistas (RANGEL, 2009, p. 560).

Com a promulgação da Lei no 1.521 de 26 de dezembro de 1951, ampliou-se a competência do Tribunal do Júri, passando a julgar também os crimes contra a economia popular, consoantes os artigos:

Art. 1․ Serão punidos, na forma desta Lei, os crimes e as contravenções contra a economia popular,

Art 2ㅇ: São crimes desta natureza:[...]

[...] Art 12. São de competência do Júri, os crimes previstos no art 2o desta Lei.[...]

No entanto, a conturbada história vivenciada pelo Brasil desde o nascimento da República alterou novamente os planos da ordem política, e sob o novo regime ditatorial é promulgada a Carta de 1967, a qual manteve a existência do Tribunal do Júri e ilusoriamente garantia sua soberania e competência, porém garantindo the o julgamento apenas dos crimes dolosos contra a vida, tal como antes da vigência da lei 1.521/51 (RANGEL, 2009, p. 561).

Governado através dos Atos Institucionais militares, o Brasil vivenciou, na década de 60, "um período negro na sua história, verdadeira vergonha para nossa historiografia". (RANGEL, 2009, p. 564). O Tribunal do Júri não se manteve atuante durante nessa parte da história, uma vez que se trata de instituto incompatível com a ditadura.

Somente com o fim da ditadura militar, alcançado com o movimento das "Diretas Já", o país pode novamente se reerguer e se reestruturar politicamente. Foi então que, em 5 de outubro de 1988, é promulgada a atual Constituição Federal do Brasil, a qual tratou de prever a existência do Tribunal do Júri no capítulo dos direitos e das garantias individuais (RANGEL 2009, p. 566). 
Tribunal do Júri: uma análise histórica e principiológica às suas decisões sobre o prisma da segurança jurídica

\section{Da base principiológica na Constituição de 88}

A Constituição Federal de 1988 prevê o Tribunal do Júri no Capítulo referente aos "Direitos e Garantias Fundamentais", mais precisamente no artigo 5ํㅡ, inciso XXXVIII, que diz respeito aos direitos individuais, espécies do gênero fundamental, in verbis:

[...] É reconhecida a instituição do júri, com a organização que the der a lei, assegurados:

a) a plenitude de defesa;

b) o sigilo das votações;

c) a soberania dos veredictos;

d) a competência para o julgamento dos crimes dolosos contra a vida; [...]

Sem o prejuízo de todos os princípios do processo penal e dos princípios gerais informadores do processo como um todo, a Carta de 1988, como visto, elenca princípios básicos e característicos que deverão ser observados nos processos a serem julgados pelo Tribunal do Júri. Imprime, assim, algumas particularidades às decisões proferidas por este instituto, se comparadas àquelas proferidas pelo Juiz singular.

\section{Plenitude de defesa}

O primeiro princípio, disposto na alínea "a" daquele referido artigo, remete ao princípio da ampla defesa, o qual trata de assegurar ao réu condições que lhe garantam trazer ao processo todos os elementos tendentes a esclarecer a verdade ou até mesmo de omitir-se ou calar-se, caso entenda necessário" (MORAES,2006, p. 93).

No entanto, este princípio diz respeito a uma expressão ainda mais abrangente que o próprio princípio da ampla defesa, ou seja, a vontade do legislador, ao instituí-lo, foi a de possibilitar ao réu uma defesa imensurável. No aspecto processual, este deverá ser assistido por um profissional habilitado para tanto, o qual utilizará de mecanismos não somente técnico, mas "podendo servir-se de argumentação extrajurídica, invocando razões de ordem social, emocional, de política criminal" (CAPEZ, 2010, p. 630).

Ainda abarcada por este princípio, está a possibilidade de autodefesa por parte do acusado, possibilitando a este, em juízo, defender a sua tese pessoal de inocência no momento do seu interrogatório. Prova disso é o disposto no artigo 482 do Código de Processo Penal, o qual preceitua que o juiz presidente, na hora de formular os quesitos aos 
jurados, deverá levar em consideração, aquilo que consta do interrogatório do acusado, sem prejuízo dos termos encerrados na pronúncia, nas decisões contidas à admissão da acusação e das alegações das partes, aquilo que consta do interrogatório do acusado (CAPEZ, 2010, p. 631).

\section{Sigilo das votações}

O segundo princípio a ser observado é o "sigilo das votações", tipicamente informador do instituto do Tribunal do Júri e único em todo órgão julgador do Poder Judiciário. A principal preocupação do legislador constituinte ao inserir esse princípio, foi a de garantir a imparcialidade, a independência, a liberdade de convicção e de opinião dos jurados.

Dispõe o artigo 93, IX, da Constituição Federal, que todos os atos do Poder Judiciário deverão ser públicos e que todas as suas decisões deverão ser fundamentadas. Entretanto, essa regra não se aplica aos atos praticados na sala secreta do Tribunal do Júri no momento dos votos dos jurados e tampouco às suas decisões, que não são fundamentadas face o princípio do sigilo das votações (CAPEZ, 2010, p. 631).

Sobre esse princípio, justifica Julio Fabbrini Mirabete (2000, p. 1032) que "a própria natureza do Júri impõe proteção aos jurados e tal proteção se materializa por meio do sigilo indispensável em suas votações e pela tranqüilidade do julgador popular, que seria afetada ao proceder a votação sob vistas do público".

\section{Soberania dos veredictos}

Outro princípio instituído pela alínea c, do artigo 5ำ, inciso XXXVIII, da Constituição Federal é a "soberania dos veredictos" dos jurados dos Tribunal do Júri, e várias são as peculiaridades implicadas a esse princípio. Este postulado "implica a impossibilidade de o tribunal técnico modificar a decisão dos jurados pelo mérito" (CAPEZ, 2010, p. 631).

Em contraposição, encontra-se a possibilidade de que, em grau de recurso, o Tribunal pode anular o julgamento do Tribunal Popular, caso verificados os requisitos necessários para tanto, e determinar a realização de um novo julgamento, não excluindo desse modo a possibilidade de se recorrer de suas decisões (MIRABETE, 2006, p. 496). 
Tribunal do Júri: uma análise histórica e principiológica às suas decisões sobre o prisma da segurança jurídica

Há que se verificar, ainda, a possibilidade de promover-se a revisão criminal da sentença condenatória transitada em julgado, que mitiga ainda mais esse princípio. Caso provada a arbitrariedade da decisão do Tribunal do Júri, pode o órgão revisor decretar a absolvição do réu e não somente proceder a anulação daquela sentença (CAPEZ, 2010, p. 631).

\section{Competência}

A competência do Tribunal do Júri está disposta no artigo 5ㅇ, inciso XXXVIII, da Constituição Federal e consiste no julgamento dos crimes dolosos contra a vida. Estes, por sua vez, se encontram tipificados pelo Código Penal, nos artigos 121 ao 128. Em espécie, se tratam dos crimes de Homicídio (simples privilegiado e qualificado); Induzimento, instigação ou auxílio ao suicídio; Infanticídio e as várias formas de Aborto, assim como também todos estes descritos na modalidade de crimes tentados (NUCCl, 2008, p. 736).

A razão pela qual se incumbiu ao crivo do Tribunal Popular essas espécies de crime foi o fato de se proteger a vida, como bem jurídico mais importante. Nessa senda, pertinente se faz transcrever as lições de Cezar Roberto Bittencourt (2001, p.27):

[...] dentre os bens jurídicos de que o indivíduo é titular e para cuja proteção a ordem jurídica vai ao extremo de utilizar a própria repressão penal, a vida destacase como o mais valiosos. A conservação da pessoa humana, que é a base de tudo, tem como condição primeira a vida, que, mais que um direito, é condição básica de todo direito individual, porque sem ela não há personalidade, e sem esta não há que se cogitar de direito individual.

Justo ressaltar que, para a maior parte dos doutrinadores (CAPEZ, 2010, p. 632), essa competência pode ser ampliada pelo legislador ordinário, sob o argumento de que o texto constitucional ao mencionar a palavra "assegurada" não quer dizer que "somente" os crimes dolosos contra a vida poderão ser objetos de julgamento por parte do Tribunal do Júri (NUCCl, 2008, p. 735).

Soma-se a isso o fato de a competência do Tribunal do Júri incluir também os crimes conexos aos crimes dolosos contra a vida que, por "força de atração (...) (artigos 76, 77 e 78, I, CPP) devem ser julgados, também, pelo Tribunal Popular" (NUCCI, 2008, p. 735). 
Interessante relembrar também que a competência estabelecida pela prerrogativa da função, também disposta em texto constitucional, é uma exceção à regra de competência ao julgamento dos crimes dolosos contra a vida estabelecida ao Tribunal do Júri, pois entre um conflito aparente de normas de mesma hierarquia prevalecerá a de natureza especial em detrimento da de caráter geral.

Sobre esse assunto estão ressalvados do julgamento pelo Tribunal Popular, ainda que acusados pela prática de crimes dolosos contra a vida, todas as autoridades elencadas no art. 29, inciso VIII, X; art. 96, inciso III; art. 102, inciso I, "b" e "c"; art. 105, inciso I, "a"; art. 108, inciso I, "a", todos da Carta de 88 , assim também os Magistrados e membros do Ministério Público.

\section{Da sua obrigatoriedade}

Conforme se pôde observar em linhas anteriores, o Tribunal do Júri é tido como direito e garantia individual. Entretanto, quando confrontado com uma norma de competência por prerrogativa da função, a competência daquele é sobrestado em razão desta. Veja-se:

[...] todas as autoridades com foro de processo e julgamento previsto diretamente pela Constituição Federal, mesmo que cometam crimes dolosos contra a vida, estarão excluídas da competência do Tribunal do Júri, pois no conflito aparente de normas da mesma hierarquia, a de natureza especial prevalecerá sobre a de caráter geral definida no art. 5ํ, XXXVIII, da Constituição Federal. (MORAES, 2006, p.96).

Como se pode observar, sempre que as regras de competência pela pregorrativa da função entrarem em conflito com a competência do Tribunal do Júri, a jurisprudência e a legislação infraconstitucional minimizam a importância desse instituto. É nesse prisma que alguns juristas questionam a obrigatoriedade de o cidadão comum, sem prerrogativa de função, ser julgado pelo tribunal júri, afinal "o Júri não é tratado como direito subjetivo, como opção do acusado, mas sim como instituição judiciária obrigatória (isto é, como mera regra de competência)" (FORTI, 2011).

Ao analisar as origens do Tribunal do Júri e a sua competência, percebe-se que o instituto em comento fora criado com o escopo de julgar os crimes passionais, que 
Tribunal do Júri: uma análise histórica e principiológica às suas decisões sobre o prisma da segurança jurídica

envolvessem sentimentos e momentos de alta emoção e não para julgar criminosos de alta periculosidade. Esse tipo de julgamento funcionou muito bem e por muito tempo em cidades provincianas, onde todas as pessoas praticamente se conheciam e contemplavam de uma vida em comum. Porém, com o surgimento das grandes metrópoles, sua razão essencial ficou defasada, dando lugar a um sentimento de medo e risco de vida ao próprio jurado, o que abriu margem de não mais haver um julgamento justo e imparcial (FORTI, 2011).

Nesse diapasão, mister se faz observar que qualquer que seja o órgão julgador, o resultado do julgamento deve ser o mais imparcial possível:

[...] em determinados casos, pode ser preferível ao réu o julgamento por um Juiz togado: a acusação será objeto de apreciação por um julgador técnico e imparcial, desprovida de maior carga emocional, em sentença fundamentada, com apreciação aprofundada das provas existentes (FORTI, 2011).

Atualmente, há quem defenda a tese de que o Tribunal do Júri, ao ser tratado como direito e garantia individual, deveria ser uma escolha do acusado a fim de lhe garantir o julgamento mais justo sob pena de se caracterizar uma obrigação e não mais se tutelar um direito (FORTI, 2011).

\section{Considerações atinentes às decisões proferidas pelo tribunal do júri à luz da} incomunicabilidade dos jurados

O Tribunal do Júri é um órgão heterogêneo devido ao fato de que em sua composição se encontram jurados leigos e um juiz togado, que terá o encargo de presidi-lo. Após se realizarem os debates em plenário, entre acusação e defesa, o juiz presidente do Tribunal do Júri deverá perguntar aos jurados se lhe restam dúvidas sobre o caso ou se já estão aptos a proferirem o seu veredicto.

Segundo Capez (2010, p. 630), eventuais dúvidas poderão ser somente de matéria de fato, conforme prevê a norma processual. Em sentido diverso, entende Nucci (2008, p. 731), segundo o qual "dúvidas quanto às questões de direito poderão ocorrer, cabendo igualmente ao magistrado togado solucioná-las". 
Caso ainda pairem dúvidas sobre os jurados, novas diligências poderão ser realizadas. Nesse caso, será dissolvido o Conselho de Sentença, por seu presidente, e deverão ser realizados os pedidos feitos pelos jurados (CAPEZ, 2010, p. 650).

Em seguida proceder-se-á, em plenário, a leitura dos quesitos que deverão ser votados pelos jurados. Quesitos são definidos como "as perguntas ou indagações, que demandam como resposta, a emissão de uma opinião ou um juízo" (NUCCl, 2008, p. 799) e, nos termos do art. 482 do Código de Processo Penal (BRASIL, 1941), corresponderão a proposições afirmativas, simples e distintas, de modo a permitirem a sua clareza e precisão.

Os quesitos a serem respondidos pelos jurados deverão ser formulados na seguinte ordem: materialidade do crime (que versará sobre a ocorrência fática do delito em tese); autoria e participação (se o ato criminoso foi realizado pelo acusado, ou com a participação de terceiro); absolvição do acusado; se há causas de diminuição de pena (caso alegadas pela defesa); se existem circunstâncias qualificadoras ou causa de aumento de pena, sendo que a observância desses últimos irá depender das respostas dos jurados para os dois primeiros quesitos, nos termos do art. 483 do Código de Processo Penal (BRASIL, 1941).

Depois de realizada a leitura e a explicação dos quesitos em plenário aos jurados, juntamente com o juiz presidente, as partes envolvidas (exceto o réu), o assistente, o querelante, o defensor do acusado, o escrivão e o oficial de justiça, dirigir-se-ão à sala especial, para que seja realizada a votação. Nesse momento, o juiz presidente determinará ao público que se retire, devendo permanecer na sala tão somente as pessoas retro mencionadas.

Antes de proceder-se à votação de cada quesito, o juiz presidente determinará a distribuição aos jurados pequenas cédulas de papel opaco, contendo 7 (sete) delas a palavra "'sim" 7 (sete) a palavra "não".

Para que o sigilo das votações seja assegurado, o oficial de justiça procederá o recolhimento das cédulas correspondentes aos votos e aquelas não utilizadas em urnas separadas. Verificados os votos, caso a resposta a qualquer dos quesitos estiver em contradição com outras já dadas, o juiz presidente explicará aos jurados em que consiste a contradição, e os submeterá novamente à votação os quesitos a que se referirem tais respostas. 
Tribunal do Júri: uma análise histórica e principiológica às suas decisões sobre o prisma da segurança jurídica

O sigilo das votações está previsto na Constituição Federal em seu artigo 5ํ, XXXVIII, "b". Para esse ato, impende destacar que, por uma questão de interesse público, devem ser proporcionadas aos jurados condições que lhes garantam liberdade para votar conforme sua livre convicção. Nos termos do que leciona Guilherme de Souza Nucci (2008, p. 811), "não se pode imaginar um julgamento firme, longe de qualquer pressão, feito à vista do público, no plenário do Júri" Não obstante, esse procedimento representa uma exceção ao princípio da publicidade dos atos do Poder Judiciário, haja vista que o Tribunal do Júri é um órgão a ele vinculado (CAPEZ, 2010, p.661).

\section{Da incomunicabilidade dos jurados}

A incomunicabilidade entre os jurados surge em nosso ordenamento jurídico pela primeira vez na legislação infraconstitucional promulgada durante o governo de Getúlio Vargas, após 1934. O autoritarismo característico desse período fez com que fosse estendido o silêncio e a censura aos jurados que comporiam o Tribunal do Júri, materializado em sua incomunicabilidade (ESTEVES, 2011).

Essa norma foi inovadora sobre esse assunto, dado que a Constituição Imperial do Brasil dispunha explicitamente que os jurados, antes de ser realizada a votação, deveriam discutir o caso entre si, de modo a legitimarem a sua decisão e dar uma maior transparência ao processo (ESTEVES, 20011).

Consiste atualmente em uma das características mais peculiares do Tribunal do Júri, e está expressamente determinada no §1ํ do artigo 466 do Código de Processo Penal, o qual dispõe “o juiz presidente também advertirá os jurados de que, uma vez sorteados, não poderão comunicar-se entre si e com outrem, nem manifestar sua opinião sobre o processo, sob pena de exclusão do Conselho e multa" (BRASIL, 1941).

Sobre essa obrigatoriedade ensina Guilherme de Souza Nucci (2008, p. 781), que:

[...] enquanto a sessão não terminar, ficam os jurados incomunicáveis, significando que não podem voltar pra casa, nem falar ao telefone ou mesmo ler mensagens em pagers, celulares ou aparelhos semelhantes. Qualquer contato com o mundo exterior, estranho às partes, aos funcionários da Vara e os outros jurados, serve para quebrar a incomunicabilidade, uma vez que ninguém poderá garantir não ter havido qualquer tipo de pressão ou sugestão para o voto. Recados urgentes podem ser transmitidos por intermédio do oficial de justiça, que os receberá, passando ao jurado, bem como deste será transmitido ao destinatário. Quando recolhidos à sala 
secreta, haverá, sempre, com eles um oficial de justiça para garantir a incomunicabilidade. Podem conversar entre si, com as partes (promotor e defensor), com funcionários e com o juiz, desde que a respeito de fatos alheios ao processo.

Consoante lecionam os defensores da tese da incomunicabilidade, essa seria uma técnica de cautela estabelecida pelo legislador, com o escopo de assegurar isenção aos jurados na formação de sua livre formação de sua convicção, assim como a livre manifestação de seu pensamento, não se deixando influenciar pelas demais opiniões dos jurados componentes do Conselho de Sentença (NUCCI, 2008, p. 798; MENDONÇA, 2009, p. 77).

A incomunicabilidade sobre as questões relativas ao processo deverá ser observada tanto por meio de palavras quanto por gestos. Tanto é verdade que, se durante a votação, um jurado balançar a cabeça como sinal de reprovação ao resultado obtido, deverá ser dissolvido o Conselho de Sentença devido à inobservância dessa exigência.

De outro turno, muito embora dogmatizada a incomunicabilidade dos jurados no Tribunal do Júri no ordenamento pátrio, parte significativa dos estudiosos sobre o assunto critica sua permanência no sistema normativo brasileiro, tal como não existe em outras partes do mundo (ESTEVES, 2011; RANGEL, p. 2009, 557).

Nas lições de Paulo Rangel (2009, p. 557):

O silêncio dos jurados é uma censura imposta com a mais forte arma que os regimes totalitários utilizam, desde a Antiguidade, para impedir a propagação de ideais que podem pôr em dúvida a organização do Poder e o seu direito sobre a sociedade.

A incomunicabilidade, ou seja, o silêncio é uma das formas de se controlar as idéias de um povo. Trata-se do controle do pensamento que vigorou no mundo antigo, grego, romano, na Idade Média, Moderna e teve seu maior rigor no século XX e o júri não ficaria de fora desse controle.

Segundo Esteves (2011), a incomunicabilidade entre os jurados surge como forma de controlar as idéias da população, funcionando como instrumento limitador do pensamento humano, pois como não mais seria permito a discussão entre eles mais fácil seria a condenação do acusado ou um julgamento parcial. E ainda acresce aludida autora (ESTEVES, 2011): 
Tribunal do Júri: uma análise histórica e principiológica às suas decisões sobre o prisma da segurança jurídica

[...] o júri passa a ser manipulado pelo exercício abusivo do poder, perdendo sua origem de tribunal popular, democrático, criado com o fim maior de retirar das mãos do déspota o poder de decisão sobe a vida dos súditos. Eis aí a consagração do desrespeito ao verdadeiro Estado Democrático de Direito.

Com razão, afinal, todas as vezes em que o mundo foi palco de regimes totalitários e muitas vezes ditatoriais, observou-se que o Estado interveio diretamente no Poder Judiciário, a fim de dificultar a liberdade e facilitar todo tipo de repressão.

Segundo os ensinamentos do filósofo contemporâneo Jürgen Habermas (1984, p. 22-43), o entendimento humano é realizado por meio da interação social dos indivíduos através da linguagem e que somente se chega a uma conclusão lógica de um raciocínio depois de verificado o "agir comunicativo" entre os interlocutores.

Sobre esse prima, afirma Paulo Rangel (2007, p. 19-20), que

\begin{abstract}
Não há dúvida, portanto, de que há no júri expresso exercício de poder que, como tal, deve ser democrático, sob pena de invalidar a decisão dos jurados. Logo, não basta a decisão ser apenas por maioria; ela tem que estar comprometida com a liberdade do outro, ou seja, deve haver um compromisso ético, na decisão, que somente será alcançado pela plena comunicação entre o conselho de sentença e sua necessária fundamentação. [...] A conversação é o instrumento através do qual os jurados vão fundamentar e exteriorizar suas opiniões sobre os fatos objeto do processo evitando o arbítrio e qualquer decisão estigmatizada.
\end{abstract}

No âmbito da cidadania, a participação popular no Tribunal do Júri nada mais é do que a concretização da democracia nas decisões do Poder Judiciário, o que ficou prejudicado em sua essência pela falta do diálogo e debate entre os compositores do Conselho de Sentença (ESTEVES, 2011).

Sobre o assunto, cumpre destacar que tramita no Congresso Nacional projeto do novo Código de Processo Penal (já aprovado pelo Senado Federal e em espera na Câmara dos Deputados), o qual contempla a permissão da comunicação entre os jurados, bem como a discussão antes de proferirem o veredicto.

\title{
Sentença prolatada pelo juiz presidente
}

Como se sabe a decisão sobre o mérito da causa é feita única e exclusivamente pelos jurados, membros do Conselho de Sentença, que se exprimirá através das suas respostas dadas às indagações que lhe são feitas pelo juiz presidente no momento da 
votação. Essa se trata de uma das espécies de decisão do Poder Judiciário brasileiro e é denominada de veredicto (TOURINHO FILHO, 2005, p. 831).

Cabe, no entanto, ao juiz presidente prolatar a sentença do acusado no mesmo sentido do veredicto dado pelos jurados, observando ainda as medidas necessárias em cada caso (condenação ou absolvição do acusado).

\section{Ausência de fundamentação}

No melhor entendimento sobre a ausência de fundamentação na sentença do Tribunal do Júri, ensina Guilherme de Souza Nucci (2008, p. 659):

No Tribunal do Júri, não há necessidade de relatório ou fundamentação, pois se trata de ato jurisdicional vinculado ao veredicto dado pelos jurados. Estes, por sua vez, em exceção constitucionalmente assimilada pelo princípio do sigilo das votações, decidem por livre conviç̧ão plena, sem fornecer qualquer motivação. Assim, descabe ao magistrado tecer comentários sobre a culpa ou inocência do acusado, bastando-lhe fixar a pena, que é justamente o dispositivo. Neste, entretanto, deve dar a fundamentação para a sanção penal escolhida e concretizada. Aliás, o relatório é despiciendo, visto que já foi feito na pronúncia. Por outro lado, a ata do julgamento espelha fielmente todas as ocorrências e alegações das partes no plenário.

Observa-se, portanto, que a sentença do Tribunal do Júri, elaborada pelo juiz presidente, prescinde de fundamentação teórica. O único fundamento que o magistrado deverá se valer são os próprios votos dos jurados, capazes de absolver ou condenar o acusado, lembrando ainda que estes não precisam sequer fundamentar os seus veredictos.

Sobre a fundamentação da sentença Guilherme de Souza Nucci acrescenta (2008, p. 813):

[...] deve-se atentar para o fato de que o juiz, no Tribunal do Júri, não deve fundamentar a decisão condenatória, pois isso coube aos jurados, que, votando em sigilo, estão desatrelados do dever de motivar o veredicto. Cabe-se, apenas, fixar a sanção [...]

Há quem entenda que essa norma, sobre a falta de motivação da sentença do Tribunal do Júri, confronta com a Constituição Federal, por desrespeitar dispositivo que preceitua que todas as decisões do Poder Judiciário deverão ser fundamentadas. Para isso, 
Tribunal do Júri: uma análise histórica e principiológica às suas decisões sobre o prisma da segurança jurídica

esclarece Fernando Capez (2010, p. 660) que as normas constitucionais que ora aparentam ser conflitantes entre si, na verdade se dirigem a institutos diferentes e, portanto, a eles excepcionais. Por essa razão, tais normas devem "ser interpretadas de acordo com os princípios que lhe são próprios [do instituto]" (CAPEZ, 2010, p. 660).

No entanto, há parte da doutrina que discorda veemente do posicionamento retro mencionado, já que defendem que a fundamentação da sentença do Tribunal do Júri não deveria se ausentar nas decisões dos jurados (ESTEVES, 2011; RANGEL, p. 2009, 557). Muito pelo contrário, por tratar-se de juízes leigos, que atuam legitimadamente em nome de toda uma sociedade, é que isso deveria ocorrer com maior especificidade.

Expressa está essa ideia nos estudos de Normanda Lizandra Lima Esteves (2011):

A resolução do conflito amparado na íntima convicção dos jurados, sem que as partes tenham conhecimento de seus motivos, é o que há de mais ultrapassado no júri, pois permite o julgamento sem qualquer relação com o fato levado ao processo, o que dá margem, e porque não dizer, fomenta o arbítrio judiciário.

A ausência de fundamentação na sentença do Tribunal do Júri se dá, particularmente, de maneira única e exclusiva, em virtude de seus princípios norteadores, tal como o sigilo das votações. $O$ fato de os jurados não fundamentarem os seus veredictos é que acarreta a ausência de motivação por parte do juiz presidente na hora de confeccionar a sentença condenatória.

Conclui ainda seu pensamento, Normanda Lizandra Lima Esteves (2011), que:

\begin{abstract}
O silêncio no tribunal do júri gera o que há de pior na teoria da culpabilidade, eis o famigerado direito penal do autor, grande conhecido do Código de Processo Penal brasileiro e que se funda não no fato praticado pelo autor, mas, sobretudo em sua personalidade, em seus antecedentes e aspecto físico. Na medida em que aos jurados se permite julgar através, apenas da íntima convicção, dificilmente será possível afastar o direito penal o em plenário, pois nesse contexto se analisa tudo, menos o fato e o indivíduo, uma vez condenado no banco dos réus resta estigmatizado.
\end{abstract}

Exsurge agora, ao final, e ao cabo das reflexões apresentados ao longo do presente trabalho, a incomunicabilidade entre os jurados pode acarretar uma série de conseqüências para o mundo jurídico, ensejando, inclusive, um julgamento desprovido de justiça e imparcialidade. 


\section{Conclusão}

O Tribunal do Júri está previsto na Constituição Federal, no capítulo referente aos "Direitos e Garantias Fundamentais", no artigo 5o, inciso XXXVIII, em virtude da tamanha importância que o constituinte originário conferiu a aludido órgão. Dessa forma, esse órgão não pode ser extirpado do ordenamento jurídico brasileiro, nem tampouco ser objeto de emenda constitucional visando minimizar o exercício deste direito.

Como se pôde observar, sua criação é de longa data e muito se aperfeiçoou com o passar dos anos. No Brasil, os jurados foram impedidos de comunicarem entre si durante toda a sessão de julgamento a partir da ditadura populista de Getúlio Vargas. Em todas as épocas em que o regime democrático se fez presente, é indiscutível que o totalitarista imponha suas vaidades também no Poder Judiciário.

Com a promulgação da Constituição Cidadã de 1988, após a ditadura militar, foi restabelecida a democracia no país. Decorrência disso, foi reinserida a participação popular nas questões relativas ao Estado, inclusive naquelas atinentes ao Poder Judiciário, por intermédio do Tribunal do Júri, em que pessoas comuns do povo decidem sobre o futuro do acusado, nos casos em que a lei assim prevê.

O fato de os jurados não poderem comunicar entre si é um legado do regime ditatorial, fato que precisa novamente ser discutido de modo a se observar a verdadeira intuição daquele órgão: a de se fazer justiça. Como conseqüência disso, a sentença do Tribunal do Júri não necessita de fundamentação, restando apenas ao juiz aplicar a pena relativa ao caso, se condenado o réu por votação dos jurados.

Como conseqüência disso, a sentença do Tribunal do Júri não necessita de fundamentação, restando apenas ao juiz aplicar a pena relativa ao caso, se condenado o réu por votação dos jurados.

No entanto, a íntima conviç̧ão dos jurados não tem o condão de conferir segurança jurídica ao julgamento. Afinal, todas as decisões judiciais devem ser motivadas, consoante disposto no art. 93, IX, da Constituição, de modo a dar transparência ao julgamento. Nessa senda, assim também deveriam ser as decisões proferidas em sede de Tribunal do Júri, mormente se tratando de juízes leigos, desprovidas de qualquer saber jurídico.

Nesse diapasão, os jurados não podem ser privados de discutirem e analisarem entre si o crime que estão julgando. Trata-se de uma das principais ferramentas da 200 
Tribunal do Júri: uma análise histórica e principiológica às suas decisões sobre o prisma da segurança jurídica

democracia; a dialética, a fim de preservar a verdadeira concepção grega do Tribunal Popular.

Vários anos se passaram desde a promulgação do Código de Processo Penal, em 1941, inclusive diversos regimes de governo, o que fez com que alguns preceitos instituídos por aquele diploma colidissem com o veiculado na Carta Democrática de 1988. Portanto, tão necessária se faz uma mudança significativa no diploma processual penal como um todo, a fim de adequá-lo às novas conjecturas da ordem jurídica contemporânea. Tanto é verdade, que já foi aprovado no Senado o projeto de reforma do Código de Processo Penal.

Resultado de longos debates em comissões, os doutrinadores vieram por sugerir ao legislador um novo texto ao que disciplina o procedimento no Tribunal do Júri. O novo artigo permitiria aos jurados que debatessem por uma hora inteira antes de proferirem o veredito, com isso se alcançaria a essência daquele órgão, não se configurando um avanço, mas a significativa retomada de um direito fundamental ofuscado com as sombras da ditadura

O projeto de reforma ainda tramita, na presente data, na Câmara dos Deputados e a incomunicabilidade dos jurados tende a ser um dos pontos mais polêmicos a ser debatido em plenário pelos parlamentares.

Espera-se que o legislador tenha a consciência de que não se pode chegar a lugar nenhum com o silêncio e que a verdadeira justiça se faz não com a vontade de uma maioria, mas sim com o resultado de uma deliberação democrática.

\section{Referências}

BITTENCOURT, Cezar Roberto. Manual de direito penal: parte especial. São Paulo: Saraiva, 2001. v. 2.

BINDER, Alberto M. Introducción al derecho procesal penal. Buenos Aires: Ad-Hoc, 1999.

BORBA, Lise Anne de. Aspectos relevantes do histórico do tribunal do júri. Jus Navigandi, Teresina, ano 7, n. 54, 1 fev. 2002. Disponível em: <http://jus.com.br/revista/texto/2695>. Acesso em: 15 maio 2011.

BRASIL, Constituição 1988. Constituição da República Federativa do Brasil. Disponível em <http://www.planalto.gov.br/ccivil_03/constituicao/constitui\%C3\%A7ao.htm>. Acesso em 16 maio 2011. 
. Decreto-lei no 3.689, de 3 de outubro de 1941. Código de Processo Penal. Diário oficial da União, Rio de Janeiro, 13 outubro 1941. Disponível em:

<http://www.planalto.gov.br/ccivil/decreto-lei/Del3689.htm>. Acesso em: 16 maio 2011.

CAPEZ, Fernando. Curso de processo penal. 17 ed. São Paulo: Saraiva, 2010.

ESTEVES, Normanda Lizandra Lima. Linguagem no Tribunal do Júri: uma questão de ética da alteridade. Disponível em:

<http://www.direitopenalvirtual.com.br/artigos/leiamais/default.asp?id=267>. Acesso em: 16 maio 2011.

FORTI, lorio Siqueira D’alessandri. O Tribunal do Júri como garantia fundamental, e não como mera regra de competência: uma proposta de reinterpretação do art. 5ㅇ, XXXVIII, da Constituição da República. Revista Eletrônica de Direito Processual, Rio de Janeiro, v. 3, [200?]. Disponível em: <http://www.arcos.org.br/periodicos/revista-eletronica-de-direitoprocessual/volume-iii/o-tribunal-do-juri-como-garantia-fundamental-e-nao-como-meraregra-de-competencia-uma-proposta-de-reinterpretacao-do-art-5o-xxxviii-da-constituicaoda-republica/>. Acesso em: 16 maio 2011.

HABERMAS, Jürgen. The theory of communicative action: reason and the rationalization of society, tradução de Thomas McCarthy. Boston: Beacon press, 1984.

MAMELUQUE, Leopoldo. Manual do novo júri. São Paulo: Revista dos Tribunais, 2008.

MENDONÇA, Andrey Borges de. Nova reforma do código de processo penal: comentada artigo por artigo. 2. ed. Rio de Janeiro: Forense; São Paulo: Método, 2009.

MIRABETE, Julio Fabbrini. Código processo penal. 7. ed. São Paulo: Atlas, 2000.

. Processo penal. 18 ed. São Paulo: Atlas, 2006.

MORAES, Alexandre de. Direito constitucional. 19. ed. São Paulo: Atlas, 2006.

NUCCl, Guilherme de Souza. Manual de processo penal e execução penal. 5. ed. 3. tir. São Paulo: Editora Revistas dos Tribunais, 2008.

. Tribunal do júri. São Paulo: Revista dos Tribunais, 2008.

RANGEL, Paulo. Direito processual penal. 16. ed. Rio de Janeiro: Lúmen Juris, 2009.

Tribunal do Júri: visão lingüística, histórica, social e dogmática. Rio de Janeiro:

Lumen juris, 2007. 
Tribunal do Júri: uma análise histórica e principiológica às suas decisões sobre o prisma da segurança jurídica

TOURINHO FILHO, Fernando da Costa. Código de processo penal comentado. 9. São Paulo: Saraiva, 2005. v. 1

Artigo recebido em 21/10/2011 e aprovado para publicação em 17/05/2012. 
ReVista de Direito PúBlico, LondRINA, V. 7, N. 1, P. 183-204, JAN./ABR. 2012. 